\title{
One-Pot Ligation-Oxidative Deselenization at Selenocysteine and Selenocystine.
}

Nicholas J. Mitchell, ${ }^{\ddagger[a]}$ Sameer S. Kulkarni, ${ }^{\ddagger[a]}$ Lara R. Malins, ${ }^{[a]}$ Siyao Wang ${ }^{[a]}$ and Richard J. Payne ${ }^{[a] \star}$

Abstract: The use of native chemical ligation at selenocysteine (Sec) with peptide thioesters and additive-free selenocystineselenoester ligation in concert with one-pot oxidative deselenization chemistry is described. These approaches provide a simple and rapid method for accessing native peptides with serine in place of $\mathrm{Sec}$ at the ligation junction. The efficiency of both variants of the one-pot ligation-oxidative deselenization chemistry is probed through the synthesis of a MUC5AC-derived glycopeptide.

\section{Introduction}

Native chemical ligation is a chemoselective reaction that enables the fusion of a peptide bearing a C-terminal thioester with a peptide possessing an $\mathrm{N}$-terminal cysteine (Cys) moiety in aqueous media. ${ }^{[1]}$ The method has revolutionized peptide and protein science by enabling access to synthetic proteins including those with modifications (Scheme 1A). ${ }^{[2]}$ One limitation of the methodology is the low natural abundance of Cys residues within proteins (ca. 1.8\%) making it a challenge to assemble protein targets with a dearth or an absence of Cys residues in the sequence using the original methodology. As a result, a number of thiol-derived amino acids have been developed that can be used as cysteine surrogates in native chemical ligation-type transformations. ${ }^{[3]}$ Importantly, following the ligation reaction, the thiol moiety can be excised through desulfurization chemistry ${ }^{[4]}$ to afford native polypeptides. ${ }^{[3 b, 5]}$
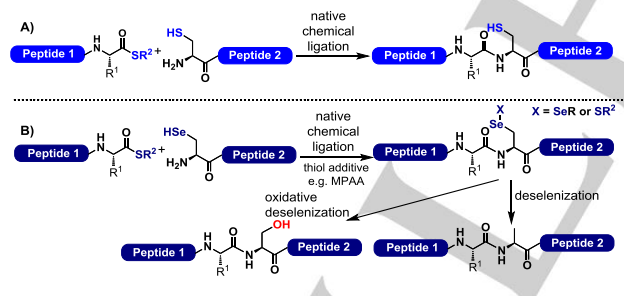

Scheme 1. A) native chemical ligation reaction: B) native chemical ligation Sec followed by deselenization (right) or oxidative deselenization (left).

A further modification of the seminal methodology has been to perform native chemical ligation reactions at the $21^{\text {si }}$ proteinogenic amino acid, selenocysteine $(\mathrm{Sec})$, rather than Cys. ${ }^{[6]}$ One of the major benefits of using Sec in place of Cys is

[a] $\quad$ Dr. N. J. Mitchell, ${ }^{\ddagger}$ Dr. S. S. Kulkarni, ${ }^{\ddagger}$ Dr. L. R. Malins, S. Wang, Prof. Dr. R. J. Payne

School of Chemistry

Sydney, NSW of Sydney

Sydney, NSW 2006, Australia

E-mail: richard.payne@sydney.edu.au
[†] These authors contributed equally to this work.

Supporting information for this article is given via a link at the end of the document. that the deselenization of Sec to alanine (Ala) can be performed under mild conditions (typically using the water soluble phosphine TCEP and a hydrogen atom source) that do not affect other unprotected Cys residues elsewhere in the sequence (Scheme 1B). ${ }^{[6 a]}$ This methodology can also be extended to ligation-deselenization at selenol-derived amino acid residues ${ }^{[7]}$ Independently, our laboratory ${ }^{[8]}$ and Metanis and co-workers, ${ }^{[9]}$ recently demonstrated that, in the presence of an oxidant to outcompete hydrogen atom abstraction, Sec can be transformed into serine (Ser) at the ligation junction which provides a further expansion of Sec-based ligations. While this oxidative deselenization can be performed using $\mathrm{O}_{2}$ as an oxidant, ${ }^{[8-9]}$ peptide cleavage products were observed on larger peptide targets. ${ }^{[8]}$ For this reason, following optimization, we arrived at oxone $\AA$ as an oxidant that could facilitate clean conversion of $\mathrm{Sec}$ to Ser in minutes in the presence of TCEP (Scheme 1B). ${ }^{[8]}$ Importantly, AParticularly, this process occurs with complete stereochemical rentention at Ser.ref8 Other mechanistically distinct approaches that enable programmed ligation at Ser ${ }^{[10}$ include the Ser/Thr ligation (STL) developed by $\mathrm{Li}$ and coworkers, ${ }^{[10 a, b, ~ e-g]}$ the oxazetidine-based ketoacid-hydroxylamine ligation (KAHA ligation) reported by Bode and co-workers ${ }^{[10}$ and cyanogen bromide-promoted conversion of methyl cysteine described by Okamoto and Kajihara. ${ }^{[10 d]}$ Notably, the methodology described herein complements the aforementioned approaches and possesses the benefit of being fast and high yielding under fully aqueous conditions.

While the oxidative Sec to Ser transformation is a useful addition to the ligation chemistry toolbox, the methodology currently suffers from the need to purify the ligation product before submission to these conditions. This is owing to interference by the aryl thiol additives ${ }^{[11]}$ typically employed in Sec-based ligation chemistry which are excellent radical traps and shutdown the radical deselenization chemistry if not removed from the ligation reaction. In its current form, this technology is therefore unacceptably laborious and time consuming in terms of purification and solvent removal steps and therefore warrants improvement.

\section{Results and Discussion}

In this work we proposed an effective solution to this synthetic bottleneck through the use of the alkyl thiol additive trifluoroethanethiol (TFET), which has been shown to facilitate native chemical ligation reactions at $\mathrm{Cys}^{\left[{ }^{[2]}\right.}$ and other thiolderived amino acids ${ }^{[13]}$ at similar rates to the gold standard thio additives e.g. MPAA. Importantly, as an alkyl thiol, TFET possesses poor radical quenching properties (unlike the ary thiol additives) and, as such, we envisaged that it would be an excellent candidate to enable one-pot peptide ligation-oxidative deselenization chemistry at Sec. In order to explore this concept, we first synthesized peptide $\mathbf{1}$ bearing an $\mathrm{N}$-terminal selenocystine residue and peptide thioesters (2-7) possessing a 
range of C-terminal functionalities by standard Fmoc-SPPS methods (see Supporting Information for details). These were next submitted to ligation reactions in aqueous buffer $(6 \mathrm{M}$ guanidine hydrochloride, $0.1 \mathrm{M}$ sodium phosphate buffer, $\mathrm{pH}$ 7.2) with the addition of TFET as a thiol additive. It should be noted that TCEP was omitted as a reductant from these reactions to prevent unwanted deselenization of peptide $\mathbf{1}$ and the resulting ligation products. As such, TFET served as both the thiol additive and the reductant. We were pleased to observe that under these conditions the ligation reactions proceeded to completion in 16-48 $\mathrm{h}$ (as judged by HPLC-MS analysis). From here, without purification the reactions were sparged with argon and diluted to $0.3 \mathrm{mM}$ in ligation buffer before the simultaneous addition of TCEP (50 eq.) and oxone ${ }^{\circledR}$ (50 eq.) to provide a final concentration of $100 \mu \mathrm{M}$ based on starting peptide 1. Each of the reactions were sampled for HPLC-MS analysis after $30 \mathrm{~min}$ at this time point it was observed that the oxidative deselenization reactions had proceeded to approximately $50 \%$ completion. A second dose of TCEP (50 eq.) and oxone $\AA$ (50 eq.) was therefore required. After an additional $30 \mathrm{~min}$ the reactions had proceeded cleanly to completion (see Supporting Information for crude HPLC data). The reactions were submitted directly to HPLC purification and provided the desired peptides (12-17; entries 1-6, Table 1) bearing Ser at the ligation junction in good yields (56-60\%) -over the two steps (see Figure $1 \mathrm{~A}$ and 1B for exemplar UPLC traces and mass spectral data of the crude ligation-oxidative deselenization from entry 3 and 7 , Table 1 with Phe thioester 4 and Gly thioester 7 and Supporting Information for all other crude reaction data).

Table 1. One-pot native chemical ligation-oxidative deselenization at Sec using peptide thioesters and TFET as a thiol additive.
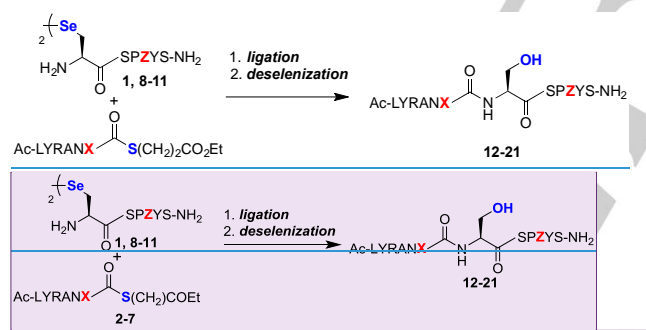

\begin{tabular}{cccc}
\hline Entry & $\begin{array}{c}\text { Ac-LYRANX-SR } \\
(\mathrm{X}=)\end{array}$ & $\begin{array}{c}\text { H-USPZYS-NH } \\
(\mathbf{Z}=)\end{array}$ & $\begin{array}{c}\text { Isolated one-pot } \\
\text { yield[a] }\end{array}$ \\
\hline 1 & Ala (2) & Gly (1) & $60 \%(\mathbf{1 2})$ \\
2 & Met (3) & Gly (1) & $58 \%(\mathbf{1 3})$ \\
3 & Phe (4) & Gly (1) & $56 \%(\mathbf{1 4})$ \\
4 & Ser (5) & Gly (1) & $57 \%(\mathbf{1 5})$ \\
5 & Leu (6) & Gly (1) & $56 \%(\mathbf{1 6})$ \\
6 & Gly (7) & Gly (1) & $56 \%(\mathbf{1 7})$ \\
7 & Gly (7) & His (8) & $71 \%(\mathbf{1 8})$ \\
\hline
\end{tabular}

\begin{tabular}{llcc}
8 & Gly (7) & Trp (9) & $57 \%(\mathbf{1 9})$ \\
9 & Gly (7) & Cys (10) & $20 \%(\mathbf{2 0})$ \\
10 & Gly (7) & Cys(PMB) (11) & $56 \%(\mathbf{2 1})$ \\
\hline
\end{tabular}

a] Isolated yields after HPLC purification. Ligation: 2-7 $(5.5 \mathrm{mM})$ and 1, 8-11 $\left(2.5 \mathrm{mM}\right.$ ) in buffer ( $6 \mathrm{M} \mathrm{Gdn} \cdot \mathrm{HCl}, 0.1 \mathrm{M} \mathrm{Na}_{2} \mathrm{HPO}_{4}$ ), TFET (2 vol.\%), rt, pH 7.2$7.4,16 \mathrm{~h}(48 \mathrm{~h}$ in the case of entry 4). Oxidative deselenization. Argon sparge of crude ligation solution, dilution to $0.3 \mathrm{mM}$ in $\mathrm{Milli}$ Q water followed by adjusted to $4.0-5.0)$ and $15 \mathrm{mM}$ oxone in Milli water $(x 2)$.

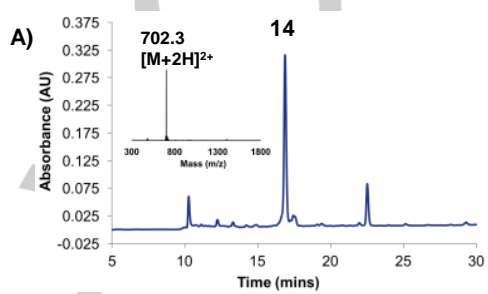

B)

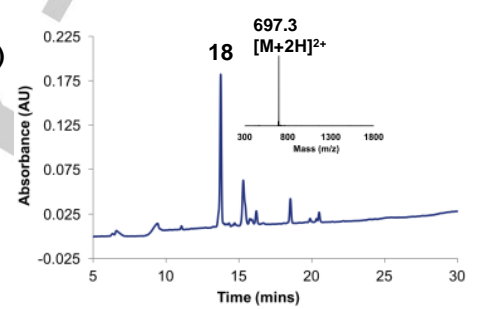

Figure 1. UPLC and mass spectral data for crude native chemical ligationoxidative deselenization reactions of: A) 1 and $\mathbf{4}$ to afford $\mathbf{1 4}$ (entry 3, Table 1) and B) 8 and 7 to afford 18 (entry 7, Table 1).

It should be noted that in the presence of a Met residue the oxidative deselenization step led to oxidation of the side chain to the sulfoxide, which required subsequent reduction using wellestablished Hackenberger conditions ${ }^{\text {ref }}$ to afford native peptide product 13 (see Supporting Information). In order to ensure that the oxidative deselenization reactions were chemoselective in the presence of the potentially sensitive His and $\operatorname{Trp}$ residues, we also prepared peptides $\mathbf{8}$ and $\mathbf{9}$ and submitted them to the reaction conditions with thioester 7 (entries 7 and 8, Table 1). We were pleased to observe clean conversion to the desired peptides (18 and 19) after a $16 \mathrm{~h}$ ligation and a $30 \mathrm{~min}$ in situ oxidative deselenization (two doses). Finally, we explored the effect of an internal Cys residue on the ligation and the oxidative deselenization reaction by preparing peptide 10 (entry 9 , Table 1). While the ligation of $\mathbf{1 0}$ to $\mathbf{7}$ proceeded smoothly in $\mathbf{1 6} \mathrm{h}$, the oxidative deselenization transformation produced a mixture of the desired Ser containing product $(\mathbf{2 0})$ and the Ala product, resulting from traditional deselenization chemistry (see Supporting Information for data). We hypothesized that the Ala product arose from intramolecular hydrogen atom transfer from
Commented [SK1]: Thioester structure needs to be corrected...! $\mathrm{S}\left(\mathrm{CH}_{2}\right)_{2} \mathrm{CO}_{2} \mathrm{Et}$ instead of $\mathrm{S}\left(\mathrm{CH}_{2}\right) \mathrm{COEt}$ 
the Cys residue to the alanyl radical intermediate proposed to be generated upon treatment of Sec with TCEP. In order to test this hypothesis we prepared peptide $\mathbf{1 1}$ whereby the side chain of Cys had been protected with a PMB ether (entry 10, Table 1). In this case the one-pot ligation-oxidative deselenization proceeded smoothly, albeit with oxidation of the thioether to the sulfoxide. The sulfoxide could be subsequently reduced to afford the PMB-protected peptide ligation product $\mathbf{2 1}$ in $56 \%$ yield after HPLC purification.

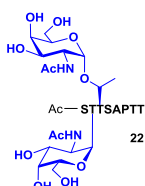

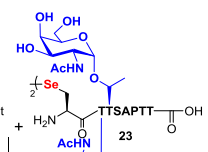
(1)

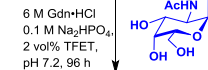
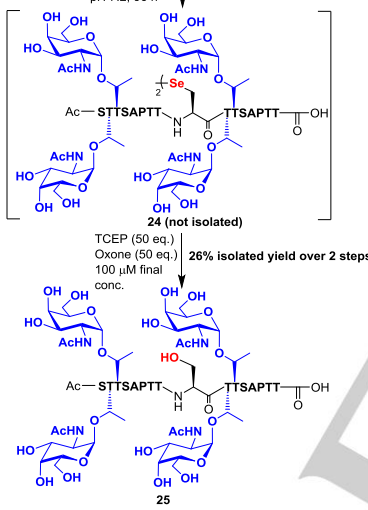

Scheme 2. Assembly of MUC5AC glycopeptide 25 via a one-pot native chemical ligation-oxidative deselenization method.

Having established the efficiency and chemoselectivity of the one-pot native chemical ligation-oxidative deselenization protocol, we were next interested in exploring the utility of the methodology for the synthesis of a small fragment of a glycoprotein, namely the mucin glycoprotein MUC5AC. Towards this end, we first prepared glycooctapeptide thioester 22 and Sec-containing glycooctapeptide $\mathbf{2 3}$ both corresponding to a single copy of the variable number tandem repeat of MUC5AC and bearing two copies each of the tumour associated $T_{N}$ antigen ( $\alpha$-GalNAc) (see Supporting Information for details). These were reacted under standard native chemical ligation conditions with TFET as the additive. Unfortunately, unlike the model systems, this ligation reaction required $96 \mathrm{~h}$ to reach completion to afford diselenide intermediate 24 . This selenylated intermediate was not purified but was submitted directly to the oxidative deselenization conditions. After three doses of TCEP (50 eq.) and oxone ${ }^{\circledR}$ (50 eq.) the Sec to Ser conversion proceeded to completion (as judged by HPLC-MS analysis) and following purification by reverse-phase HPLC, tetraglycosylated MUC5AC peptide 25 was isolated in $26 \%$ yield over the two steps.

One of the drawbacks of using $\mathrm{Sec}$ to facilitate ligation under a native chemical ligation manifold, i.e. with thioesters, is that the rates of ligation can be significantly slower than the analogous reaction at Cys. This is owing to the redox potential of $\mathrm{Sec}(-381$ $\mathrm{mV}$ ) meaning that Sec prefers to exist as the oxidized diselenide selenocystine in solution. As such, even though thiol reductants such as MPAA and TFET are used in the reaction, only a small steady state concentration of the selenol is generated leading to sluggish reaction rates. This is a particular problem for the reaction of sterically hindered thioesters, such as the Thr thioester 22 in the MUC5AC example (see Scheme 2), making these reactions less useful from a preparative synthetic standpoint. In theory, the increased nucleophilicity of the selenol/selenolate (compared to the thiol/thiolate of Cys) should lead to significantly enhanced rates if the reactivity of this functionality could be fully harnessed. We have recently reported a solution to this problem through the development of additivefree selenocystine-selenoester ligation chemistry. ${ }^{[14]}$ This method involves simple mixing of a peptide dimer bearing an $\mathrm{N}$ terminal selenocystine moiety and a peptide phenyl selenoester in aqueous buffer. Ligation reactions proceed at unprecedented reaction rates, even for sterically hindered $\mathrm{C}$-terminal residues on the selenoester fragment. Importantly, because there are no additivesafter removing the diphenyldiselenide (DPDS generated during ligation, deselenization of Sec to Ala can be effected in situ to afford native peptide products.

Given the rapid rates of the additive-free selenocystineselenoester ligation reaction we were interested in coupling the methodology with oxidative deselenization chemistry to enable rapid access to native peptide products bearing Ser at the ligation junction in place of the $\mathrm{Sec}$ residue used to facilitate the ligation chemistry. Towards this end, peptide pheny selenoesters 26-32 were first synthesized via Fmoc-SPPS (see Supporting Information) and reacted with peptide diselenide dimer 1 under the additive-free manifold. Briefly, this involved mixing 1 with a given phenyl selenoester (26-32) in buffer $(6 \mathrm{M}$ $\mathrm{Gdn} \cdot \mathrm{HCl}, 0.1 \mathrm{M} \mathrm{Na}_{2} \mathrm{HPO}_{4}$ ) at room temperature and $\mathrm{pH} 6.2$ (Table 2). Reactions were monitored by UPLC-MS and, gratifyingly, all had procceded cleanly to afford the desired ligation product within $60 \mathrm{sec}$ (with the exception of the reaction with Val selenoester 31 which required $5 \mathrm{~min}$ to reach completion, see entry 6 , Table 2 ). The reactions were subsequently submitted to the oxidative deselenization conditions without purification. This involved extraction of diphenyldiselenide (DPDS) with hexane, dilution with ligation buffer, followed by simultaneous treatment with TCEP and oxone $\AA$. It should be noted that the majority of reactions required only a single treatment with TCEP and oxone $\AA^{\circledR}$ to proceed to completion. Exceptions were -the ligation product generated from reaction with Phe selenoester 28 (entry 3, Table 2) which required an additional dose of TCEP and oxone ${ }^{\circledR}$ to completely convert the $\mathrm{Sec}$ at the ligation junction to Ser, and the ligation product generated from reaction with $\mathrm{Val}$ selenoester 
31 (entry 6, Table 2) which required initial treatment with hydrazine hydrate before oxidative deselenization-due to the presence of significant amounts of a selenoester linked product. It is known that the ligation product is significantly selenoesterified in the presence of excess selenoester and can be transformed back to the ligation product by treating the mixture with 2 vol.\% hydrazine hydrate (see Supporting Information for crude HPLC data). Importantly, all of the one-po additive-free ligation-deselenization reactions proceeded cleanly to afford native peptide products (see Figure 2A for exempla UPLC trace and mass spectral data of the crude ligationoxidative deselenization from entry 5 , Table 2 with Leu selenoester $\mathbf{3 0}$ and Supporting Information for all other crude reaction data). Interestingly, we did not observe any oxidation of the thioether side chain of the Met residue (entry 2, Table 2 ) under the oxidative deselenization condition, suggesting that a small amount of DPDS remaining from the hexane extraction can suppress this process. Following HPLC purification, the desired ligation products $\mathbf{1 2 - 1 7}$ and $\mathbf{3 3}$ were afforded in good yields $(50-71 \%$ over 2 steps, entries $1-7$, Table 2$)$.

Table 2. One-pot additive free selenocystine-selenoester ligation-oxidative deselenization.

\begin{tabular}{|c|c|c|c|}
\hline Entry & $\begin{array}{c}\text { Ac-LYRANX-SePh } \\
(\mathrm{X}=)\end{array}$ & $\begin{array}{c}\mathrm{H} \text {-USPZYS-NH } \\
(\mathrm{Z}=)\end{array}$ & $\begin{array}{l}\text { Isolated one-pot } \\
\text { yield[a] }\end{array}$ \\
\hline 1 & Ala (26) & Gly (1) & $59 \%(12)$ \\
\hline 2 & Met (27) & Gly (1) & $50 \%(13)$ \\
\hline 3 & Phe (28) & Gly (1) & $66 \%{ }^{b}(14)$ \\
\hline 4 & Ser (29) & Gly (1) & $56 \%(15)$ \\
\hline 5 & Leu (30) & Gly (1) & $69 \%(16)$ \\
\hline 6 & $\operatorname{Val}(\mathbf{3 1})$ & Gly (1) & $71 \%^{\mathrm{c}}(\mathbf{3 3})$ \\
\hline 7 & Gly (32) & Gly (1) & $63 \%(17)$ \\
\hline 8 & Gly (32) & His (8) & $73 \%(18)$ \\
\hline 9 & Gly (32) & $\operatorname{Trp}(\mathbf{9})$ & $60 \%(19)$ \\
\hline
\end{tabular}

a Isolated yields after HPLC purification. Ligation: $\mathbf{2 6 - 3 0}$ and $\mathbf{3 2}(5 \mathrm{mM}, 6.5 \mathrm{mM}$

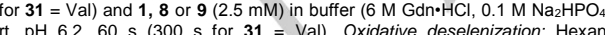
extraction and dilution of crude ligation soxlution to $0.3 \mathrm{mM}$ in buffer $(6 \mathrm{M}$ $\mathrm{Gdn} \cdot \mathrm{HCl}, 0.1 \mathrm{M} \mathrm{Na} 2 \mathrm{HPO}_{4} \cdot \mathrm{pH} 7$ 1) followed by simultaneous addition of an eq. vol. of $15 \mathrm{mM}$ TCEP in buffer ( $6 \mathrm{M} \mathrm{Gdn} \cdot \mathrm{HCl}, 0.1 \mathrm{M} \mathrm{Na}_{2} \mathrm{HPO}_{4}, \mathrm{pH} 4.5-5.0$ ) and $15 \mathrm{mM}$ oxone ${ }^{\circledR}$ in buffer $\left(6 \mathrm{M} \mathrm{Gdn} \cdot \mathrm{HCl}, 0.1 \mathrm{M} \mathrm{Na}_{2} \mathrm{HPO}_{4}, \mathrm{pH} 7.1\right)$. ${ }^{\circ}$ Additiona dose of TCEP (50 eq.) and oxone $(50 \mathrm{eq}$.) added at $t=30 \mathrm{~min}$, cLigation was treated with 2 vol.\% hydrazine hydrate for $15 \mathrm{~min}$ before oxidative

We also wanted to interrogate the chemoselectivity of these one-pot transformations in the presence of oxidation-prone amino acids such as His and Trp. As such we reacted peptide diselenide dimers 8 and 9 with selenoester 32 under the additive-free ligation conditions, followed by in situ oxidative deselenization. Both reactions proceeded cleanly to afford native peptide products 18 and 19 in $73 \%$ and $60 \%$ isolated yields, respectively, following HPLC purification (see Figure 2B for crude UPLC and mass spectral data for reaction of $\mathbf{9}$ with $\mathbf{3 2}$ entry 9 , Table 2 ).
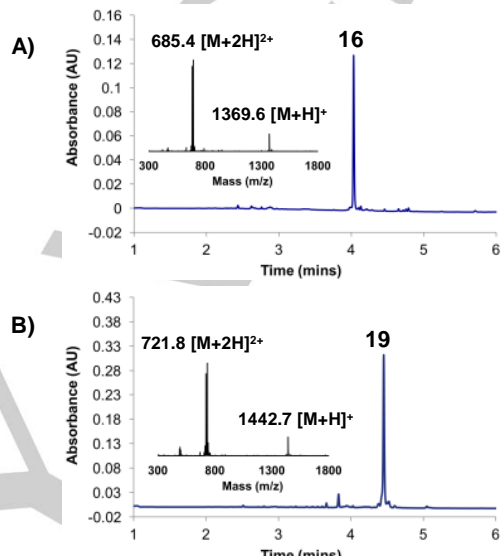

Figure 2. UPLC and mass spectral data for crude additive-free ligationoxidative deselenization reactions of: A) $\mathbf{1}$ and $\mathbf{3 0}$ to afford $\mathbf{1 6}$ (entry 5, Table 2) and B) 9 and $\mathbf{3 2}$ to afford 19 (entry 9 , Table 2).

Having demonstrated the efficient and operationally simple nature of the one-pot additive-free ligation oxidative deselenization protocol on model systems, we were interested in comparing the efficiency of the methodology on the MUC5AC system that proved to be low yielding under the native chemical ligation manifold. To this end, glycopeptide selenoester $\mathbf{3 4}$ was synthesized by Fmoc-SPPS and ligated with glycopeptide diselenide dimer $\mathbf{2 3}$ under additive-free ligation conditions. Afte $5 \mathrm{~min}$ the ligation had reached completion (as judged by UPLC MS analysis) and the DPDS precipitate was subsequently extacted with hexane prior to treatment with hydrazine hydrate to hydrazinolyze the unproductive ligation product bearing a selenoester moiety to afford exclusively the diselenide dimer. Treatment with oxone $\AA$ and TCEP then effected the oxidative deselenization, which after HPLC purification provided glycopeptide 25 in $46 \%$ isolated yield over three steps. This represented a significant improvement in ligation yield and reaction rate compared to the analogous steps via the native chemical ligation-oxidative deselenization pathway. 


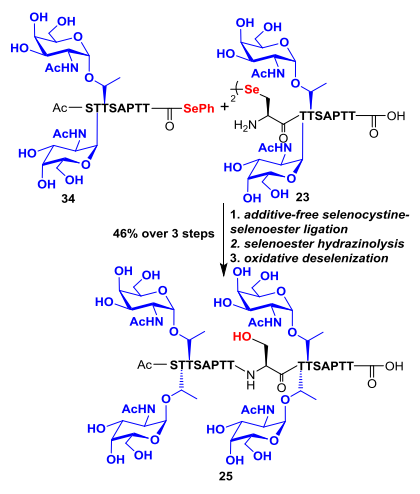

Scheme 3. Assembly of MUC5AC glycopeptide via the one-pot additive-free selenocystine-selenoester ligation-oxidative deselenization method. $34(6.5 \mathrm{mM})$ in buffer $\left(6 \mathrm{M} \mathrm{Gdn} \cdot \mathrm{HCl}, 0.1 \mathrm{M} \mathrm{Na} 2 \mathrm{HPO}_{4}\right)$, rt, $\mathrm{pH} 6.25 \mathrm{Min}$ 34 (6.5 mine extraction; selenoester hydrazinolysis: 2 vol.\% hydrazine hydrate Hexane extraction; selenoester hydrazinolysis: 2 vol.\% hydrazine hydrate,
$30 \mathrm{~min}$; oxidative deselenization: dilution of crude ligation solution to $0.3 \mathrm{mM}$ in buffer (6 M Gdn $\cdot \mathrm{HCl}, 0.1 \mathrm{M} \mathrm{Na}_{2} \mathrm{HPO}_{4}, \mathrm{pH}$ 7.1) followed by simultaneous addition of an eq. vol. of $15 \mathrm{mM} \mathrm{TCEP}$ in buffer $\left(6 \mathrm{M} \mathrm{Gdn} \cdot \mathrm{HCl}, 0.1 \mathrm{M} \mathrm{Na}_{2} \mathrm{HPO}\right.$ $\mathrm{pH} 4.5-5.0)$ and $15 \mathrm{mM}$ oxone in buffer $\left(6 \mathrm{M} \mathrm{Gdn} \cdot \mathrm{HCl}, 0.1 \mathrm{M} \mathrm{Na}_{2} \mathrm{HPO}_{4}, \mathrm{pH} 7.1\right.$ ).

\section{Conclusions}

In summary, we have described the use of native chemical ligation between Sec-containing peptides and peptide thioesters, coupled with one-pot oxidative deselenization chemistry, to afford native peptides bearing a Ser residue at the ligation junction in place of Sec. We also demonstrate that oxidative deselenization chemistry can be used following an additive-free selenocystine-selenoester ligation in a one-pot fashion. Both strategies were employed in the one-pot synthesis of a glycosylated fragment of the glycoprotein MUC5AC with the one-pot additive-free ligation-oxidative deselenization approach providing better yields and in a shorter time frame compared to the native chemical ligation-based approach.

\section{Experimental Section}

General: Low-resolution mass spectra were recorded on a Shimadzu 2020 mass spectrometer (ESI) operating in positive mode. MALDI-TOF mass spectra were measured on a Bruker autoflex speed MALDI-TOF instrument using a matrix of Sinapinic acid in water/acetonitrile $(7: 3 \mathrm{v} / \mathrm{v})$ instrument using a matrix of Sinapinic acid in water/acetonitrile $(7: 3 \mathrm{v} / \mathrm{v})$
containing 0.1 vol\% trifluoroacetic acid (TFA) in reflectron mode. containing 0.1 vol\% trifluoroacetic acid (TFA) in reflectron mode.
Analytical reverse-phase HPLC was performed either on a Waters System 2695 separations module with an Alliance series column heater at $30^{\circ} \mathrm{C}$ and 2996 photodiode array detector or a Waters Acquity UPLC system equipped with a PDA e $\lambda$ detector $(\lambda=210-400 \mathrm{~nm})$, Sample Manager FAN and Quaternary Solvent Manager (H-class) modules. Peptides were analyzed on the HPLC system using a Waters Sunfire 5 em (C-18) $2.1 \times 150$ edm colum or an Xbridge BEH300 5 um (C-18) 2.1 $\mu \mathrm{m}(\mathrm{C}-18) 2.1 \times 150 \mathrm{~mm}$ colum or an Xbridge BE $13005 \mu \mathrm{m}$ (C-18) 2.1 $x 150 \mathrm{~mm}$ column at a flow rate of $0.2 \mathrm{~mL}$ min ${ }^{-1}$ or the UPLC system a flow rate of $0.6 \mathrm{~mL} \mathrm{~min}^{-1}$. Both instruments were operated using a mobile phase composed of $0.1 \%$ TFA in $\mathrm{H}_{2} \mathrm{O}$ (Solvent $\mathrm{A}$ ) and $0.1 \%$ TFA in acetonitrile (Solvent B). The analysis of the chromatograms was conducted using Empower 3 Pro software (2010). Preparative reversephase HPLC was performed using a Waters 600 Mulisolvent Delivery phase System and Waters 500 pump with 2906 photodiode array detector or Waters $490 \mathrm{E}$ Programmable wavelength detector operating at 230 and $280 \mathrm{~nm}$. A Waters Sunfire or an Xbridge BEH300 $5 \mu \mathrm{m}$ (C-18) $19 \times 150$ $\mathrm{mm}$ preparative column operating at a flow rate of $7 \mathrm{~mL} \mathrm{~min}^{-1}$ were employed using a mobile phase of $0.1 \%$ TFA in water (Solvent A) and $0.1 \%$ TFA in acetonitrile (Solvent B) and a linear gradient as specified. Model peptide ligation-oxidative deselenization products were purified on a Waters Sunfire or an Xbridge BEH300 $5 \mu \mathrm{m}$ (C-18) $10 \times 250 \mathrm{~mm}$ semipreparative column operating at a flow rate of $4 \mathrm{~mL} \mathrm{~min}^{-1}$ using a mobile phase of $0.1 \%$ TFA in we Phase of 0.1\% TFA in war (Solvetonitrile Solvent B) and a inear gradient as speciled. Reaction yields for al model ligation reactions are calculated based on the amount of isolated peptide product relative to the theoretical reaction yield. Yields were no adjusted to account for the removal of aliquots for reaction monitoring (e.g. LC-MS, pH measurement).

Materials: Commercial materials were used as received unless otherwise noted. Amino acids, coupling reagents and resins were obtained from Novabiochem or GL Biochem. Reagents that were not obtained from Novabiochem or GL Biochem. Reagents that were no commercially available were synthesized following literature procedures as indicated in the experimental. N,N-dimethylformamide (DMF) was
obtained as peptide synthesis grade from Merck or Labscan. (Boc-Sec$\mathrm{OH})_{2}$ was synthesized from commercially available $\left(\mathrm{H}_{2} \mathrm{~N}-\mathrm{Sec}-\mathrm{OH}\right)_{2}$ (Mimotopes, VIC, Australia).

General procedures for SPPS of peptides and glycopeptides following the Fmoc strategy (Iterative peptide assembly) Deprotection: The resin was treated with $20 \%$ piperidine/DMF $(2 \times 3 \mathrm{~mL}$ $3 \mathrm{~min})$ and washed with DMF $(5 \times 3 \mathrm{~mL}), \mathrm{CH}_{2} \mathrm{Cl}_{2}(5 \times 3 \mathrm{~mL})$ and DMF (5 $\times 3 \mathrm{~mL}$ ).

General amino acid coupling: A solution of protected amino acid (4 eq.), PyBOP (4 eq.) and NMM (8 eq.) in DMF (final concentration $0.1 \mathrm{M}$ ) ( was adC

Capping: Acetic anhydride/pyridine (1:9 v/v) was added to the resin ( 3 $\mathrm{mL})$. After $3 \mathrm{~min}$ the resin was washed with DMF $(5 \times 3 \mathrm{~mL}), \mathrm{CH}_{2} \mathrm{Cl}_{2}(5 \times$ $3 \mathrm{~mL})$ and DMF $(5 \times 3 \mathrm{~mL})$.

Cleavage: A mixture of TFA, triisopropylsilane (TIS) and water (90:5:5 $\mathrm{v} / \mathrm{v} / \mathrm{v}$ ) was added to the resin (For Met or Cys containing peptides, TFA:TIS:thioanisole: $\mathrm{H}_{2} \mathrm{O}(85: 5: 5: 5 \mathrm{v} / \mathrm{v} / \mathrm{v} / \mathrm{v})$ was used). After $2 \mathrm{~h}$, the resin was washed with TFA $(3 \times 2 \mathrm{~mL})$.

Work-up: The combined cleavage and TFA wash solutions were concentrated under a stream of nitrogen either to dryness or to $<5 \mathrm{~mL}$. In the latter case, $30 \mathrm{~mL}$ of diethyl ether was added to precipitate the peptide, the suspension cooled at $-20^{\circ} \mathrm{C}$ and centrifuged at $4000 \mathrm{rpm}$ for $5 \mathrm{~min}$. The pellet or dry residue was then dissolved in water containing $0.1 \%$ TFA, filtered, purified by preparative HPLC and analyzed by LC-MS and ESI mass spectrometry.

Automated solid-phase peptide synthesis: Automated Fmoc-SPPS was carried out on a Biotage Initiator ${ }^{+}$Alstra microwave peptide
synthesizer equipped with an inert gas manifold. General synthetic protocols for Fmoc-deprotection and capping were carried out in accordance with the manufacturer's specifications. Standardized amino acid couplings were performed for $20 \mathrm{~min}$ at $50^{\circ} \mathrm{C}$ under microwave irradiation in the presence of amino acid (0.3 M in DMF), Oxyma (0.5 M in DMF) and $N N^{\prime}$-disopropylcarbodiumide $(0.5 \mathrm{M}$ in DMF). cleavage and work-up were carried out as described above for manual SPPS. 
General protocol for one-pot ligation-oxidative deselenization using peptide alkyl thioesters 2-7: Peptide thioesters (1.1 eq.) were dissolved in degassed buffer $\left(6 \mathrm{M} \mathrm{Gdn} \cdot \mathrm{HCl}, 0.1 \mathrm{M} \mathrm{Na}_{2} \mathrm{HPO}_{4}\right.$, adjusted to $\mathrm{pH} 7.0$ $7.5,11 \mathrm{mM}$ concentration). The solution was added to the diselenide ( 2 mg, 1.0 eq. also in $6 \mathrm{M} \mathrm{Gdn} \cdot \mathrm{HCl}, 0.1 \mathrm{M} \mathrm{Na}_{2} \mathrm{HPO}_{4}, \mathrm{pH} 7.0-7.5,5 \mathrm{mM}$ concentration with respect to the dimer) to give a final concentration of $2.5 \mathrm{mM}$ with respect to the selenopeptide dimer. The final $\mathrm{pH}$ of the $2.5 \mathrm{mM}$ with respect to the selenopeptide dimer. The final $\mathrm{pH}$ of the
solution was measured and adjusted to $7.0-7.5$, using $2 \mathrm{M} \mathrm{NaOH}$ or $1 \mathrm{M}$ $\mathrm{HCl}$ solution, if necessary. Addition of 2 vol.\% TFET was followed by agitation on an orbital shaker at rt for $16-48 \mathrm{~h}$, at which point LC-MS analysis indicated complete consumption of the starting selenopeptide. The crude solution was sparged with argon and diluted to $300 \mu \mathrm{M}$ by the addition of MilliQ water. A solution of TCEP (50 eq) in water (15 mM) was prepared and adjusted to a final $\mathrm{pH}$ of $4.0-5.0$ with $2 \mathrm{MNaOH}$. was pepar solution of Oxone (50 eq) in water (15 mM) was also peptide solution was treated simultaneously with equal volumes of the aqueous solutions of TCEP and Oxone to give a final concentration of $100 \mu \mathrm{M}$ with respect to the peptide ligation product and a final reaction $\mathrm{pH}$ of 4.2-4.5. The solution was agitated on an orbital shaker at rt and monitored by LC-MS analysis. A second dose of aqueous TCEP $(\mathrm{pH}$ adjusted to 4.0-5.0) and aqueous Oxone was necessary in all cases (see analytical peptide data for details). Following completion of the reaction, crude peptide products were concentrated on a lyophilizer (16 h). The crude peptide prody samples were reconstited in water containing $0.1 \%$ TFA and purified $0.1 \%$ TFA in water (Solvent A) and $0.1 \%$ TFA in acetonitrile (Solvent B) with a linear gradient as specified. All peptide products were isolated a white solids following lyophilization.

General protocol for one-pot ligation-oxidative deselenization using peptide selenoesters 26-32: The diselenide dimer peptide H-USPGYS$\mathrm{NH}_{2}(2.0 \mathrm{mg}, 1.5 \mu \mathrm{mol})$ and a selenoester Ac-LYRANX-SePh $(3.0 \mu \mathrm{mol})$ were separately dissolved in ligation buffer $(6 \mathrm{M} \mathrm{Gdn} \cdot \mathrm{HCl}, 0.1 \mathrm{M}$ $\mathrm{Na}_{2} \mathrm{HPO}_{4}, \mathrm{pH}=7.1$ ) to a concentration of $5 \mathrm{mM}$ and $10 \mathrm{mM}$ with respect $\mathrm{Na}_{2} \mathrm{HPO}_{4}, \mathrm{pH}=7.1$ ) to a concentration of $5 \mathrm{mM}$ and $10 \mathrm{mM}$ with respect
to the diselenide dimer and selenoester respectively (Note: concentration of $13 \mathrm{mM}$ was used if $X=\mathrm{Va}$ ). The selenoester solution was added in one portion to the solution of diselenide and the reactio mixture left at rt with intermittent agitation. Analytical HPLC-MS analysis indicated consumption of the diselenide and formation of ligation products within $60 \mathrm{sec}$. The ligation reaction mixture was washed with equal volume of hexane to remove diphenyldiselenide (DPDS) and diluted to 300 M in ligation buter. A solution of TCEP (50 eq) in ligtion diluted to 300 MM in ligation buter. A solution of TCEP (50 eq.) in ligation buffer $(15 \mathrm{mM})$ was prepared and adjusted to a final $\mathrm{pH}$ of $4.5-5.0$ with 2
$\mathrm{M} \mathrm{NaOH}$. A solution of Oxone ( 50 eq.) in ligation buffer $(15 \mathrm{mM})$ was also prepared. The peptide solution was treated simultaneously with equal volumes of the aqueous solutions of TCEP and Oxone to give a fina concentration of $100 \mu \mathrm{M}$ with respect to the peptide ligation product and a final reaction $\mathrm{pH}$ of 4.5-6.0. The solution was agitated on an orbital shaker at it and monitored by LC-MS analysis. Following completion of the reaction, the crude solution was directly infused onto an HPLC column eluting wh $100 \%$ wate (wh $0.1 \%$ TFA) betore purifying $v$ ia preparative reverse-phase HPLC using a linear gradient as specified employing a mobile phase of $0.1 \%$ TFA in water (Solvent A) and $0.1 \%$
TFA in acetonitrile (Solvent B). All peptide products were isolated as white solids following lyophilization.

\section{Acknowledgements}

The authors acknowledge an ARC Future Fellowship (FT130100150) and Discovery Project grant (DP160101324).

Keywords: peptides • ligation • oxidative deselenization • glycopeptides $\cdot$ synthesis

[1] a) P. E. Dawson, T. W. Muir, I. Clark-Lewis, S. B. H. Kent, Science 1994, 266, 776-779; b) P. E. Dawson, S. B. H. Kent, Ann. Rev. Biochem. 2000, 69, $923-960$

a) S. B. H. Kent, Chem. Soc. Rev. 2009, 38, 338-351; b) R. J. Payne, C. H. Wong, Chem. Commun. 2010, 46, 21-43; c) S. Bondalapati, M. Jbara, A. Brik, Nat. Chem. 2016, 8, 407-418. a) L. R. Malins, R. J. Payne, Aust. J. Chem. 2015, 68, 521-537; b) L. R. Malins, R. J. Payne, Curr. Opin. Chem. Biol. 2014, 22, 70-78. a) L. Z. Yan, P. E. Dawson, J. Am. Chem. Soc. 2001, 123, 526$46,9248-9252$.

a) H. Rohde, O. Seitz, Biopolymers $2010,94,551-559 \cdot$ b) P. E. a) H. Rohde, O. Seitz, Biopolymers 2010, 94, 551-559; b) P. E.

Payne, in Protein Ligation and Total Synthesis I, Springer

International Publishing, 2014, pp. 27-87; d) C. P. Hackenberge, D. Schwarzer, Angew. Chem. Int. Ed. 2008, 47, 10030-10074. a) N. Metanis, E. Keinan, P. E. Dawson, Angew. Chem. Int. Ed. 2010, 49, 7049-7053; b) M. D. Gieselman, L. Xie, W. A. van der Donk, Org. Lett. 2001, 3, 1331-1334; c) R. Quaderer, A. Sewing, D. Dery N. Metanis Angew. Chem. Int Ed 2016, 55, 992-995; R. Malins, N. J. Mitchell, R. J. Payne, J. Pept. Sci. 2014, 20, 64-77; f) R. J. Hondal, B. L. Nilsson, R. T. Raines, J. Am. Chem. Soc 2001, 123, 5140-5141.

a) S. D. Townsend, Z. Tan, S. Dong, S. Shang, J. A. Brailsford, S. J. Danishefsky, J. Am. Chem. Soc. 2012, 134, 3912-3916; b) L. R. Malins, R. J. Payne, Org. Lett. 2012, 14, 3142-3145. . R. Malins, N. J. Mitchell, S. McGowan, R. J. Payne, Angew. Chem. Int. Ed. 2015, 54, 12716-12721.

S. Dery, P. S. Reddy, L. Dery, R. Mousa, R. N. Dardashti, N. Metanis, Chem. Sci. 2015, 6, 6207-6212.

a) C. L. Lee, X. Li, Curr. Opin. Chem. Biol. 2014, 22, 108-114; b) X. Li, H. Y. Lam, Y. Zhang, C. K. Chan, Org. Lett. 2010, 12, 17241727; c) I. Pusterla, J. W. Bode, Nat. Chem. 2015, 7, 668-672; d R. Okamoto, Y. Kajihara, Angew. Chem. Int. Ed. 2008, 47, 5402 5406; e) Y. Zhang, C. Xu, H. Y. Lam, C. L. Lee, X. Li, Proc. Natl Acad. Sci. U. S. A. 2013, 110, 6657-6662; f) H. Liu, X. Li, Org. Wong. H. Y Chow, X Li, J Am Chem Soc. 2016, 138, 1047710484

[11] a) M. Jbara, M. Seenaiah, A. Brik, Chem. Commun. 2014, 50, 12534-12537; b) K. M. Cergol, R. E. Thompson, L. R. Malins, P. Turner, R. J. Payne, Org. Lett. 2013, 16, 290-293; c) T. Moyal, H. P. Hemantha, P. Siman, M. Refua, A. Brik, Chem. Sci. 2013, 4, 2496-2501.

12] R. E. Thompson, X. Liu, N. Alonso-García, P. J. B. Pereira, K. A. Jolliffe, R. J. Payne, J. Am. Chem. Soc. 2014, 136, 8161-8164. a) L. R. Malins, A. M. Giltrap, L. J. Dowman, R. J. Payne, Org. Lett. R. Malins, R. J. Payne, Org Lett. 2015, 17, 4902-4905; c) S. Bondalapati, W. Mansour, M. A. Nakasone, S. K. Maity, M. H. Glickman, A. Brik, Chem. Eur. J. 2015, 21, 7360-7364.

[14] N. J. Mitchell, L. R. Malins, X. Liu, R. E. Thompson, B. Chan, L.
Radom, R. J. Payne, J. Am. Chem. Soc. 2015, 137, 14011-14014

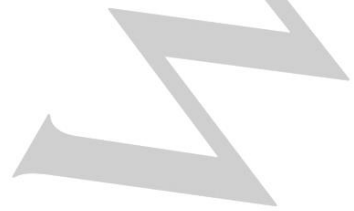




\section{FULL PAPER}

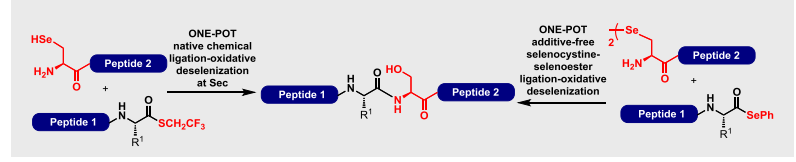

Native chemical ligation at selenocysteine (Sec) with peptide thioesters and additive-free selenocystine-selenoester ligation in concert with one-pot oxidative deselenization chemistry is described. These approaches provide a simple and rapid means to access native peptides with serine in place of Sec at the ligation junction.
Nicholas J. Mitchell, $\neq[a]$ Sameer S.

Kulkarni, ${ }^{\ddagger[a]}$ Lara R. Malins, ${ }^{[a]}$ Siyao

Wang ${ }^{[a]}$ and Richard J. Payne ${ }^{[a] *}$

\section{Page No. - Page No.}

One-Pot Ligation-Oxidative

Deselenization at Selenocysteine and Selenocystine. 